\title{
Gene expression in implant surgery patients: a description of bone and inflammation
}

\section{markers}

Expressão gênica de pacientes submetidos à cirurgia de implante: Descrição de marcadores ósseos e inflamatórios

Expresión genética de pacientes sometidos a cirugía de implantes: descripción de marcadores óseos e inflamatórios

Renata Falchete do Prado

ORCID: https://orcid.org/0000-0001-5970-0464 São Paulo State University, Brazil

E-mail: renatafalchete@hotmail.com

Alessandra Manchini Cardoso Tarallo

ORCID: https://orcid.org/0000-0002-7369-706X

São Paulo State University, Brazil

E-mail: lemanchini@hotmail.com

Luana Marotta Reis de Vasconcellos

ORCID: https://orcid.org/0000-0003-4344-0578

São Paulo State University, Brazil

E-mail: luanamrv@gmail.com

Alecsandro Moura Silva

ORCID: https://orcid.org/0000-0001-8820-3993

São Paulo State University, Brazil

University of Taubate, Brazil

E-mail: alecsms@yahoo.com.br

Lafayette Nogueira Junio

ORCID: https://orcid.org/0000-0001-8443-6722

São Paulo State University, Brazil

E-mail: lafayette.nogueira-junior@unesp.br

Guilherme de Siqueira Ferreira Anzaloni Saavedra

ORCID: https://orcid.org/0000-0001-7108-0544 São Paulo State University, Brazil E-mail: saavedra@ict.unesp.br

Renato Sussumo Nishioka

ORCID: https://orcid.org/0000-0002-1458-601X São Paulo State University, Brazil

E-mail: renato.s.nishioka@unesp.br

Alexandre Luiz Souto Borges

ORCID: https://orcid.org/0000-0002-5707-7565

São Paulo State University, Brazil

E-mail: alexanborges@gmail.com

\begin{abstract}
This research describes the gene expression of molecules related to inflammation and bone metabolism in all patients submitted to dental implant surgery attended at a Brazilian institution. A convenience sample was collected over 2 years. The bone samples were processed for extraction of total RNA and reverse transcription of cDNA. Relative quantification by real-time polymerase chain reaction of target genes was performed. The sample was characterized demographically and according heath conditions. The patients were grouped. The control group was composed of 17 healthy patients, 6 patients were included in the antihypertensive therapy group, 3 were smokers, another 3 were smokers and were under antihypertensive treatment, and 3 were ex-smokers (smoked for 10 years but had quit for at least 5 years). The ex-smoker group presented the highest values, and the Hypertensive group presented the lowest values of Macrophage colony-stimulating factor, Osteonectin, Bone Morphogenetic Protein II, and Integrin. All smokers demonstrated expression values comparable to the Control group. The highest expression values of Osteopontin, RUNX, and Alkaline Phosphatase were observed in the Hypertensive and the Smoker group, while the lowest values were found in the Hypertensive group. Smokers, Ex-smokers, and the Control group demonstrated similar values. As conclusion, gene downregulation was observed in patients under anti-hypertensive therapy. Smoke seems to reduce expression of genes involve in bone formation and increase genes responsible for resorptive activity.
\end{abstract}


This pattern of genic expression may be involved in higher implant loss, observed in smokers. Stop smoke seems to return expression of some of these genes.

Keywords: Ex-smoker; Genes; Hypertension; Osseointegration; Smoking.

\section{Resumo}

Esta pesquisa descreve a expressão gênica de moléculas relacionadas à inflamação e ao metabolismo ósseo em todos os pacientes submetidos à cirurgia de implante dentário atendidos em uma instituição brasileira. Uma amostra de conveniência foi coletada ao longo de 2 anos. As amostras ósseas foram processadas para extração do RNA total e transcrição reversa do cDNA. A quantificação relativa por reação em cadeia da polimerase, em tempo real, dos genes alvo, foi realizada. Os pacientes foram agrupados. O grupo controle foi composto por 17 pacientes saudáveis, 6 foram incluídos no grupo em terapia anti-hipertensiva, 3 eram fumantes, outros 3 eram fumantes e estavam em tratamento anti-hipertensivo e 3 eram ex-fumantes (fumaram por 10 anos, mas pararam de fumar por pelo menos 5 anos). $\mathrm{O}$ grupo ex-fumante apresentou as maiores expressões e o grupo Hipertenso apresentou os menores valores de Fator estimulador de colônias de macrófagos, Osteonectina, Proteína Morfogenética Óssea II e Integrina. Os maiores valores de expressão de Osteopontina, RUNX e fosfatase alcalina foram observados no grupo Hipertenso e Fumante, enquanto os menores valores foram encontrados no grupo Hipertenso. Fumantes, Ex-fumantes e o grupo Controle demonstraram valores semelhantes. Como conclusão o fumo parece reduzir a expressão de genes envolvidos na formação óssea e aumentar genes responsáveis pela atividade reabsortiva. Esse padrão de expressão gênica pode estar envolvido na maior perda de implantes observada em fumantes. Parar de fumar parece retornar a expressão de alguns desses genes.

Palavras-chave: Ex-fumante; Genes; Hipertensão; Osseointegração; Fumo.

\section{Resumen}

Esta investigación describe la expresión génica de moléculas de la inflamación y el metabolismo óseo en pacientes sometidos a cirugía de implantes dentales tratados en una institución brasileña. Se recogió una muestra de conveniencia durante 2 años. Las muestras de hueso se procesaron para la extracción del ARN total y la transcripción inversa del ADNc. Se realizó la cuantificación relativa por reacción en cadena de la polimerasa, en tiempo real, de los genes diana. Los pacientes fueron agrupados em: sanos, grupo en terapia antihipertensiva, grupo fumadores, grupo fumadores y estaban en tratamiento antihipertensivo y grupo exfumadores (fumaban durante 10 años, pero dejar de fumar durante al menos 5 años). El grupo de exfumadores tuvo las expresiones más altas y el grupo de hipertensos tuvo los valores más bajos de Factor estimulante de colonias de macrófagos, osteonectina, proteína morfogenética ósea e integrina. Todos los fumadores demostraron valores de expresión comparables a los del grupo de control. Los valores más altos de expresión de Osteopontina, RUNX y fosfatasa alcalina se observaron en los grupos Hipertenso y Fumador, mientras que los valores más bajos se encontraron en el grupo Hipertenso. Fumadores, exfumadores y el grupo Control mostraron valores similares. Como conclusión, el humo parece reducir la expresión de genes implicados en la formación ósea y aumentar los genes responsables de la actividad de resorción. Este patrón de expresión génica puede estar involucrado en una mayor pérdida de implantes, observada en fumadores. Detener el humo parece devolver la expresión de algunos de estos genes.

Palabras clave: Exfumador; Genes; Hipertensión; Osteointegración; Fumar.

\section{Introduction}

Although dental implants have a high success rate, failures still occur despite adequate clinical conditions. A percentage of implant loss of around 2.5 and 6.5\% is relevant (Broker et al., 2018). Observation of multiple implant loss in certain groups of individuals (clustering phenomenon) suggests that host response may influence implant failure (Montes et al., 2009, 2007).

Becker et al. revealed statistically significant influences of tobacco smoking on long-term implant survival rate, demonstrating that $57.14 \%$ of smokers lost at least one implant. In comparison, $16.9 \%$ of non-smokers had lost at least one implant(Becker et al., 2016). The pooled analysis indicated a significantly increased risk of implant failure in smokers in the study by Chambrone et al. 2014 (Chambrone et al., 2014).

Many studies have reported genetic molecular bone patterns after implant loss (Maria I.G. Campos et al., 2005; Maria Isabela Guimarães Campos et al., 2005; Costa-Junior et al., 2013; Montes et al., 2009; Pereira et al., 2019; Pigossi et al., 2012). Thus, we proposed to evaluate the bone before to the implant placement in seeking a differentiation factor between patients with different health situations. 
The development of polymerase chain reaction (PCR) has generated vast benefits in the study of gene expression. PCR also plays an important role in various dentistry fields. For example, genetic analysis using PCR for identifying susceptibility to periodontitis will help to determine the type and frequency of treatment. Studies based on PCR analyzing various immune and inflammatory markers are useful in understanding the pathogenesis of periodontitis (Maheaswari, Kshirsagar, \& Lavanya, 2016). Samples from oral tumors, subgingival plaque, saliva, blood, gingival tissue, and buccal mucosa scraping were tested using the PCR technique to identify microorganisms, genetic polymorphisms, and to quantify mRNA expression. Another important application of PCR is its use as a diagnostic tool in peri-implantitis before to implant surgery for detecting bacteria and identifying the risk of peri-implantitis development (Maheaswari et al., 2016). However, genetic bone patterns in different health conditions in patients prior to implant placement have not been previously explored.

In view of the above, we designed this study to perform an epidemiological analysis in which a convenience sample served to evaluate the gene expression of important molecular markers of inflammation and bone metabolism in patients receiving dental implants.

\section{Methodology}

The convenience sample was obtained by invitation of all patients who underwent dental implant surgery in a Brazilian institution during the past two years. The research protocol was approved by the local Human Research Ethics Committee and registered on the Brazil Platform (Plataforma Brasil - PlatBr CAAE 83499418.1.0000.0077). Bone samples $(n=39)$ were obtained during implant surgery using surgical suction with collectors from 32 patients (some patients had two different surgeries in separate places). Inclusion and exclusion criteria are described below. Signing the informed consent was a prerequisite to participation. This work followed the Strengthening the Reporting of Observational Studies in Epidemiology (STROBE) statement: guidelines for reporting.

The inclusion criteria for the study were: age between 18 and 70 years, and require and adhere to treatment with 1 up to 6 implants.

Exclusion or non-inclusion criteria included: patient's wish to be excluded from the study; bone grafting in the last 6 months; chronic bone metabolism diseases; a history of chemotherapy in the last 5 years; a history of head or neck radiotherapy in the last 5 years; severe discrepancies of maxillo-mandibular in syndromic patients.

\section{Health conditions}

A complete anamnesis collecting data related to current systemic health was detailed in institutional records. Family and medical history, use of medications, and addictions were meticulously explored and tabulated.

The team of implant dentists used their expertise to carry out rehabilitation planning. Complete treatment began with implant surgery and continued with a healing time of approximately 4 months, implant exposure, prosthetic molding, and finally prosthetic rehabilitation. Each case had their individuality preserved regarding surgical maneuvers and materials used which were determined by each implant dentist of the team.

As soon as the patient agreed with the rehabilitation planning, each patient was submitted to Cone-beam computed tomography (CBCT) using an i-CAT scanner (Imaging Sciences, Hatfield, PA, USA) with the following acquisition parameters: $120 \mathrm{kVp}, 10 \mathrm{~mA}$, reconstructed voxel size of $0.25 \mathrm{~mm}$, and a field of view (FOV) of $8 \times 16 \mathrm{~cm}$. CBCT images were taken for evaluation of implant placement.

Bone sample collection was performed during implant surgery. Chlorhexidine antisepsis was executed, and the patient was anesthetized by the local anesthetic technique; an incision and a full-thickness flap release were performed. A surgical bone collector suction system was used as soon as the implant recipient bed was prepared, and the perforation was performed 
under constant irrigation with sterile pyrogen-free saline to avoid bone warming.

\section{Molecular Analysis}

The bone collector (Indusbello Londrina PR Brazil) was then uncoupled from the suction system at the end of the perforation, and a sterile spatula 7 was used for sample collection which was immediately placed in a free RNase and DNase microcentrifuge tube containing $1 \mathrm{~mL}$ of Trizol Reagent (ThermoFisher Scientific California, USA). The samples were stored at $-80^{\circ} \mathrm{C}$ after collection. All tubes received a code number to avoid bias. The researcher was blind to which group the sample belonged to.

RNA extraction was subsequently performed as follows: samples were incubated for 5 minutes in ultrasound to lyse, homogenize tissues and allow complete dissociation of the nucleoproteins complex. Next, $0.2 \mathrm{~mL}$ of chloroform (VETEC Duque de Caxias - SP - Brazil) was added, then incubated for 2 minutes. Samples were centrifuged for 15 minutes at $4^{\circ} \mathrm{C}$ $(12,000 \times \mathrm{g})$. The aqueous phase containing the RNA was transferred to a new tube and $0.5 \mathrm{~mL}$ of isopropanol (Sigma-Aldrich São Paulo Brazil) was added to the aqueous phase. Samples were then incubated at room temperature for 10 minutes and centrifuged for 10 minutes at $4^{\circ} \mathrm{C}(12,000 \times \mathrm{g})$. The pellet at the bottom of the tube was washed after discarding the supernatant. Ethanol at $75 \%(1 \mathrm{~mL})$ was used to wash the RNA pellet which was centrifuged for 5 minutes at $4^{\circ} \mathrm{C}(7500 \times \mathrm{g})$. The supernatant was again discarded, and the RNA pellet was dried and resuspended in $20 \mu \mathrm{L}$ of DPEC water (DEPC-Treated Water Ambion Life Technology Waltham, Massachusetts, USA). RNA quantities and purities were obtained using a Nanodrop 2000 spectrophotometer (Thermo Fisher Scientific Inc. — Wilmington, DE, USA).

The cDNA synthesis was performed using SuperScript ${ }^{\mathrm{TM}}$ III First-Strand Synthesis SuperMix (Invitrogen Life Technologies Corporation California, USA). First, the following solutions were combined in a $0.2 \mathrm{~mL}$, thin-walled PCR tube on ice: $400 \mathrm{ng}$ of total RNA, $1 \mu \mathrm{L}$ of $50 \mathrm{ng} / \mu \mathrm{L}$ random hexamers, $1 \mu \mathrm{L}$ of annealing buffer, and RNase/DNase-free water to complete $8 \mu \mathrm{L}$. Tubes were incubated in a thermal cycler at $65^{\circ} \mathrm{C}$ for 5 minutes, then immediately place on ice for 1 minute. Still on ice, $2 X$ First-Strand Reaction Mix $(10 \mu \mathrm{L})$ and SuperScript ${ }^{\mathrm{TM}}$ III/RNaseOUT ${ }^{\mathrm{TM}}$ Enzyme Mix $(2 \mu \mathrm{L})$ reagents were added, mixed and incubated during 5 minutes at $25^{\circ} \mathrm{C}$, followed by 50 minutes at $50^{\circ} \mathrm{C}$. Reactions terminated at $85^{\circ} \mathrm{C}$ for 5 minutes and tubes containing samples were stored at $-20^{\circ} \mathrm{C}$.

RT-PCR was performed with a Step one Plus 7000 Real-Time PCR System (Applied Biosystems California, USA) using Platinum SYBR Green qPCR Super Mix-UDG (Invitrogen Life Technologies Corporation California, USA) and specific primers (IDT Integrated and Technologies California USA). The gene expression of alkaline phosphatase, osteocalcin, osteopontin, osteonectin, bone sialoprotein II, bone morphogenetic protein, RUNX2, osterix, prostaglandin E2 synthase, transforming growth factor- $\beta$ (TFG- $\beta$ ), integrin $\beta-1$, Interleukin 6 , macrophage colony stimulating factor (MCS-F), apolipoprotein and collagen-1 (as the housekeeping gene) were evaluated. Previously validated detail of primer sequences may be consulted elsewhere(do Prado et al., 2015; Gagliardi, de VasConCellos, Cairo, Rabelo, \& Do Prado, 2018).

Reactions were prepared in 96 well plates (Applied Biosystems - Life technologies) with each well containing 12.5 $\mu \mathrm{L}$ of Platinum ${ }^{\circledR}$ SYBR ${ }^{\circledR}$ Green qPCR SuperMix-UDG, $0.5 \mu \mathrm{L}$ of forward primer $(10 \mu \mathrm{M}), 0.5 \mu \mathrm{L}$ of reverse primer $(10 \mu \mathrm{M})$, $0.5 \mu \mathrm{L}$ of ROX dye $(2.5 \mu \mathrm{M}), 9 \mu \mathrm{L}$ of RNase/DNase-free water and $2 \mu \mathrm{L}$ of cDNA template.

RT-PCR was performed as follows: one cycle at $50^{\circ} \mathrm{C}$ for 2 minutes hold (UDG incubation), one cycle at $95^{\circ} \mathrm{C}$ for 2 minutes hold, 40 cycles at $95^{\circ} \mathrm{C}$ during 15 seconds and $60^{\circ} \mathrm{C}$ during 30 seconds, and finally the melting curve analysis. The RT-PCR reactions were performed in duplicate.

After the RT-PCR reactions, the cycle threshold values were used for relative quantification. The Comparative CT Method ( $\triangle \Delta C T$ Method)(Livak \& Schmittgen, 2001) was performed to compare gene expression among the patients. A young male health donor was considered as the calibrator. Three genes were tested to choose the normalizing gene: Beta-Actin, Type 
I Collagen, and Bone Morphogenetic Protein using NormFinder software (MOMA - Department of Molecular Medicine Aarhus University Hospital Denmark).

\section{Statistical analysis}

Sample normality was tested using the Shapiro-Wilk normality test. The GraphPad Prism 6 software program (GraphPad Software San Diego, CA, USA) was used to perform descriptive statistical analysis and to create comparative graphs. Inferential statistical analysis may be consulted in Supplemental file S1.

\section{Results}

\section{Health conditions}

We collected samples from 40 patients. Eight patients were excluded; the housekeeping gene did not present amplification, interrupting $\Delta \Delta \mathrm{CT}$ relative quantification.

Among the last 32 patients, 10 were male and 22 were female. The mean age was 50 years with a standard deviation of 15.8 (ranging from 19 to 78). Five patients presented two or more implants and each implant was used as a different sample. A total of $7.7 \%$ of surgeries were performed in the anterior region and $38.5 \%$ in the posterior region of the maxilla, while $5.1 \%$ of implants were placed in the anterior and $48.7 \%$ in the posterior region of the mandible.

Thus, five groups of patients were formed according to the main relevant health conditions. Table 1 presents the demographic aspects of patients and the correspondent group. The Control group demonstrated no relevant clinical conditions; the hypertensive group was formed by patients under anti-hypertensive drug therapy; patients in the smoker group were assumed to smoke cigarettes daily; and the hypertensive smoker group was composed of patients summing the blood hypertension under therapy and smoking. The Ex-smoker group was composed of patients who had smoked for 10 years but had stopped smoking at least 5 years ago.

Table 1 - Demographic data.

\begin{tabular}{c|c|c|c|c|c}
\hline \hline Record & Gender & Age & Region & Group & Drug(s) \\
\hline \hline 14498 & F & 69 & posterior mandible & Control & \\
\hline 14498 & F & 69 & posterior mandible & Control & \\
\hline 14498 & F & 69 & posterior mandible & Control & \\
\hline 24032 & M & 41 & posterior mandible & Control & \\
\hline 27492 & M & 22 & anterior maxilla & Control & \\
\hline 36678 & F & 38 & posterior mandible & Control & \\
\hline 36678 & F & 38 & posterior mandible & Control & \\
\hline 44640 & F & 67 & posterior mandible & Control & \\
\hline 48590 & F & 45 & posterior maxilla & Control & \\
\hline 48756 & F & 63 & posterior maxilla & Control & \\
\hline 50792 & F & 54 & posterior maxilla & Control & \\
\hline 55208 & F & 19 & anterior mandible & Control & \\
\hline 55418 & F & 31 & posterior maxilla & Control & \\
\hline 56112 & F & 71 & posterior mandible & Control & \\
\hline
\end{tabular}


Research, Society and Development, v. 10, n. 3, e46910313650, 2021

(CC BY 4.0) | ISSN 2525-3409 | DOI: http://dx.doi.org/10.33448/rsd-v10i3.13650

\begin{tabular}{|c|c|c|c|c|c|}
\hline 56112 & $\mathrm{~F}$ & 71 & posterior mandible & Control & \\
\hline 56944 & $\mathrm{~F}$ & 35 & posterior mandible & Control & \\
\hline 58132 & $\mathrm{M}$ & 27 & posterior mandible & Control & \\
\hline 58150 & $\mathrm{~F}$ & 53 & posterior mandible & Control & \\
\hline 58255 & $\mathrm{M}$ & 42 & posterior mandible & Control & \\
\hline 58316 & $\mathrm{~F}$ & 52 & posterior mandible & Control & \\
\hline 58316 & $\mathrm{~F}$ & 52 & posterior maxilla & Control & \\
\hline 59001 & $\mathrm{~F}$ & 50 & anterior maxilla & Control & \\
\hline 41519 & $\mathrm{~F}$ & 41 & posterior maxilla & Smoker & \\
\hline 56860 & $\mathrm{M}$ & 27 & anterior maxilla & Smoker & \\
\hline 58234 & $\mathrm{~F}$ & 35 & posterior maxilla & Smoker & \\
\hline 45119 & $\mathrm{M}$ & 67 & posterior maxilla & Ex-Smoker & \\
\hline 58353 & $F$ & 64 & posterior mandible & Ex-Smoker & \\
\hline 59713 & $\mathrm{M}$ & 65 & posterior maxilla & Ex-Smoker & \\
\hline 59713 & $\mathrm{M}$ & 65 & posterior mandible & Ex-Smoker & \\
\hline 41376 & $\mathrm{~F}$ & 59 & posterior maxilla & Hypertensive & Losartan 50mg \\
\hline 47139 & M & 64 & posterior maxilla & Hypertensive & $\begin{array}{c}\text { perindopril } 4 \mathrm{mg} / \text { indapamide } \\
1,25 \mathrm{mg}\end{array}$ \\
\hline 49288 & M & 71 & posterior maxilla & Hypertensive & $\begin{array}{l}\text { Potassium Losartan 50mg/ } \\
\text { Hydrochlorothiazide } 25 \mathrm{mg}\end{array}$ \\
\hline 56206 & $\mathrm{~F}$ & 55 & posterior mandible & Hypertensive & - \\
\hline 56282 & $\mathrm{M}$ & 54 & posterior maxilla & Hypertensive & enalapril maleate $10 \mathrm{mg}$ \\
\hline 57124 & $\mathrm{~F}$ & 53 & posterior maxilla & Hypertensive & Nifedipine $20 \mathrm{mg}$ \\
\hline 46735 & $\mathrm{~F}$ & 78 & anterior mandible & Hypertensive and Smoker & Nifedipine $10 \mathrm{mg}$ \\
\hline 52969 & $\mathrm{~F}$ & 62 & posterior mandible & Hypertensive and Smoker & Captopril 25mg \\
\hline 52969 & $\mathrm{~F}$ & 62 & posterior mandible & Hypertensive and Smoker & Captopril 25mg \\
\hline 52969 & $\mathrm{~F}$ & 62 & posterior mandible & Hypertensive and Smoker & Captopril 25mg \\
\hline 56696 & $\mathrm{~F}$ & 45 & posterior maxilla & Hypertensive and Smoker & Losartan 50mg /Atenolol 25mg \\
\hline
\end{tabular}

Source: Authors.

\section{Molecular Analysis}

The best RNA integrity obtained during sample collection evaluating a 260/280 ratio was 1.94 , and the lower ratio accepted was 1.44 (mean $1.63 \pm 0.11$ )

Collagen I was selected as a preferred housekeeping gene using NormFinder software. After using cycle threshold values for relative quantification, groups of patients were compared through descriptive statistics and graphs. The results are summarized in Table 2 and Figures 1, 2 and 3. 
Research, Society and Development, v. 10, n. 3, e46910313650, 2021

(CC BY 4.0) | ISSN 2525-3409 | DOI: http://dx.doi.org/10.33448/rsd-v10i3.13650

Table 2 - Descriptive statistics. Mean \pm Standard Deviation of relative quantification of genes are presented for each group

\begin{tabular}{|c|c|c|c|c|c|}
\hline Group/gene & Control & Hypertensive & $\begin{array}{l}\text { Hypertensive } \\
\text { and Smoker }\end{array}$ & Smoker & Ex-Smoker \\
\hline BMP II & $0.5847 \pm 1.146$ & $0.135 \pm 0.2919$ & $0.5006 \pm 0.919$ & $0.5493 \pm 0.442$ & $1.950 \pm 1.943$ \\
\hline Osteonectin & $1.675 \pm 1.78$ & $0.6717 \pm 0.720$ & $1.754 \pm 1.257$ & $1.785 \pm 1.624$ & $2.148 \pm 1.454$ \\
\hline Integrin & $0.6598 \pm 1.044$ & $0.3926 \pm 0.503$ & $1.021 \pm 0.9722$ & $1.648 \pm 1.426$ & $2.464 \pm 4.118$ \\
\hline$M C S F$ & $1.371 \pm 2.223$ & $0.7673 \pm 1.219$ & $2.2 \pm 2.582$ & $2.027 \pm 2.431$ & $3.429 \pm 4.722$ \\
\hline Osteopontin & $1.23 \pm 2.103$ & $0.471 \pm 0.7036$ & $2.214 \pm 2.528$ & $0.7896 \pm 0.445$ & $1.783 \pm 1.251$ \\
\hline$A L P$ & $0.7573 \pm 2.633$ & $0.1505 \pm 0.221$ & $1.333 \pm 2.588$ & $0.648 \pm 0.6902$ & $0.3945 \pm 0.466$ \\
\hline$R U N X 2$ & $1.207 \pm 2.495$ & $0.1127 \pm 0.282$ & $3.338 \pm 7.493$ & $0.915 \pm 0.8876$ & $2.066 \pm 1.673$ \\
\hline Osteocalcin & $3.246 \pm 18.86$ & $0.1124 \pm 0.143$ & $0.352 \pm 0.3553$ & $0.3138 \pm 0.412$ & $0.8072 \pm 0.851$ \\
\hline Apolipoprotein & $\begin{array}{c}2.348 \mathrm{e}+008 \pm \\
1.073 \mathrm{e}+009\end{array}$ & $0 \pm 0$ & $0 \pm 0$ & $\begin{array}{c}5.833 \mathrm{e}+007 \pm 1.4 \\
29 \mathrm{e}+008\end{array}$ & $\begin{array}{c}5.951 \mathrm{e}+009 \pm 1.3 \\
91 \mathrm{e}+010\end{array}$ \\
\hline Interleukin 6 & $1.344 \pm 3.116$ & $0.1502 \pm 0.315$ & $1.357 \pm 1.848$ & $0.298 \pm 0.3966$ & $22.26 \pm 30.54$ \\
\hline Osterix & $\begin{array}{c}8.17 \mathrm{e}+07 \pm 3.72 \mathrm{e} \\
+08\end{array}$ & 0 & $\begin{array}{c}6.52 \mathrm{e}+06 \pm 20610 \\
000\end{array}$ & 0 & $\begin{array}{c}1.01 \mathrm{e}+09 \pm 2.85 \mathrm{e} \\
+09\end{array}$ \\
\hline Prostaglandin & $0.143 \pm 0.3137$ & $0.017 \pm 0.0461$ & $0.004 \pm 0.013$ & $0.9679 \pm 1.61$ & $3.424 \pm 8.22$ \\
\hline Bone Sialoprotein & $1.854 \pm 2.763$ & $1.352 \pm 2.674$ & $2.056 \pm 2.795$ & $0.847 \pm 0.9648$ & $2.839 \pm 3.284$ \\
\hline$T G F-\beta$ & $0.9431 \pm 1.514$ & $0.216 \pm 0.2466$ & $0.9462 \pm 1.268$ & $2.526 \pm 3.321$ & $1.101 \pm 2.827$ \\
\hline
\end{tabular}

Source: Authors. 
Figure 1 - Comparisons among the groups of the data for BMPII, Osteonectin, Integrin and M-CSF genes. The three groups that contained smokers or ex-smokers presented higher expression of these transcripts.
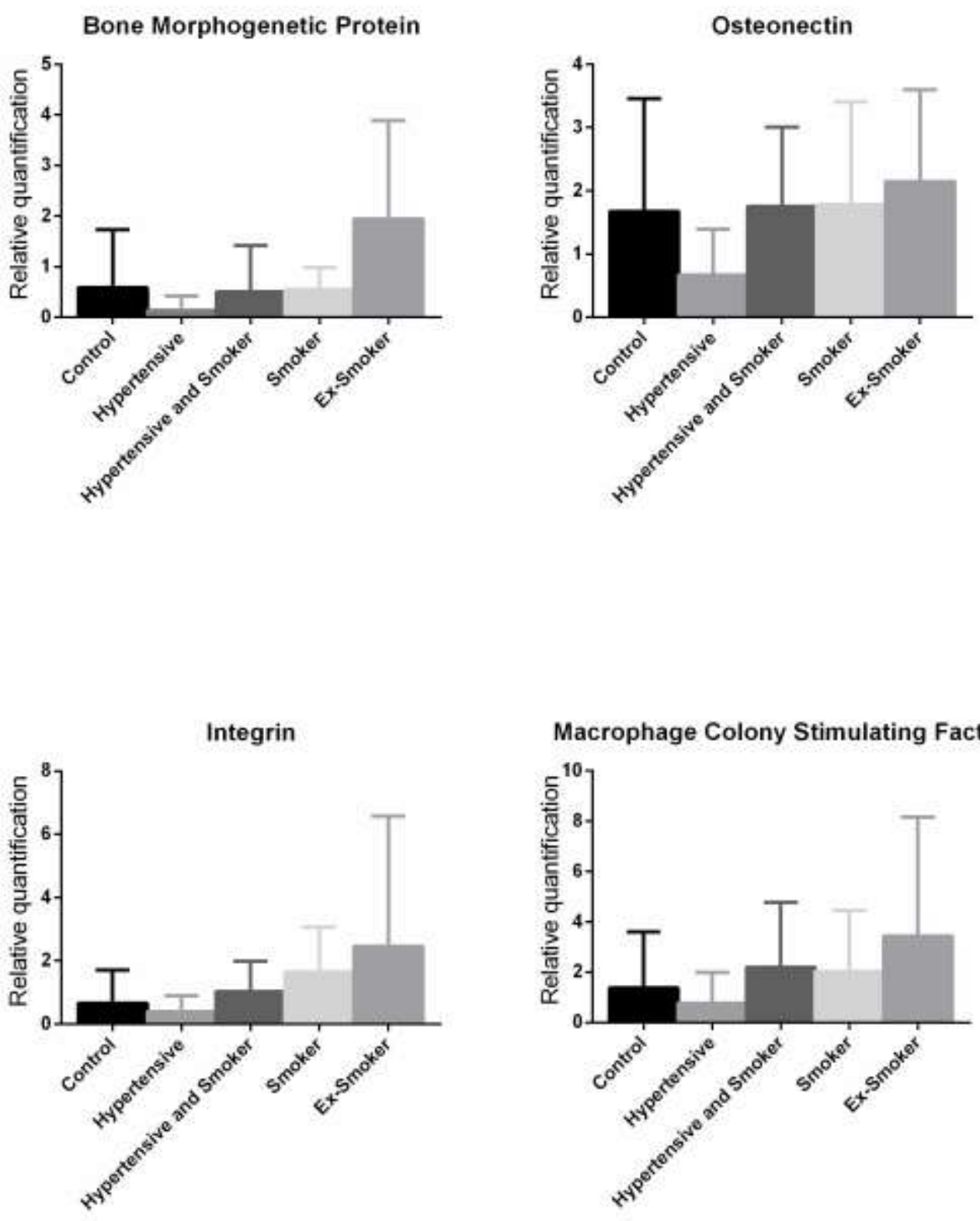

Source: Authors. 
Figure 2 - Comparisons among the groups of the data for Osteopontin, ALP, RUNX2 and osteocalcin genes. OPN, ALP and RUNX 2 upregulation was observed in Hypertensive and Smoker group.
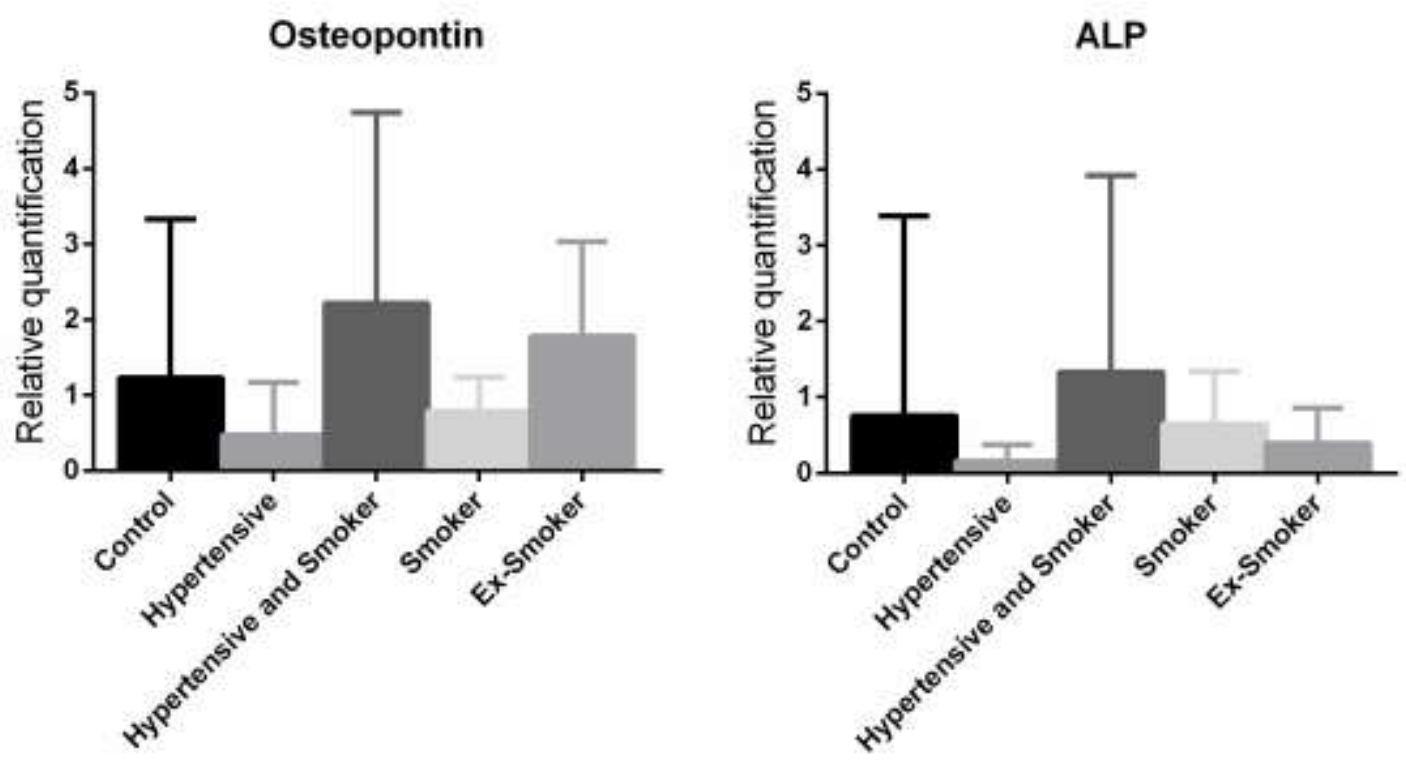

RUNX 2
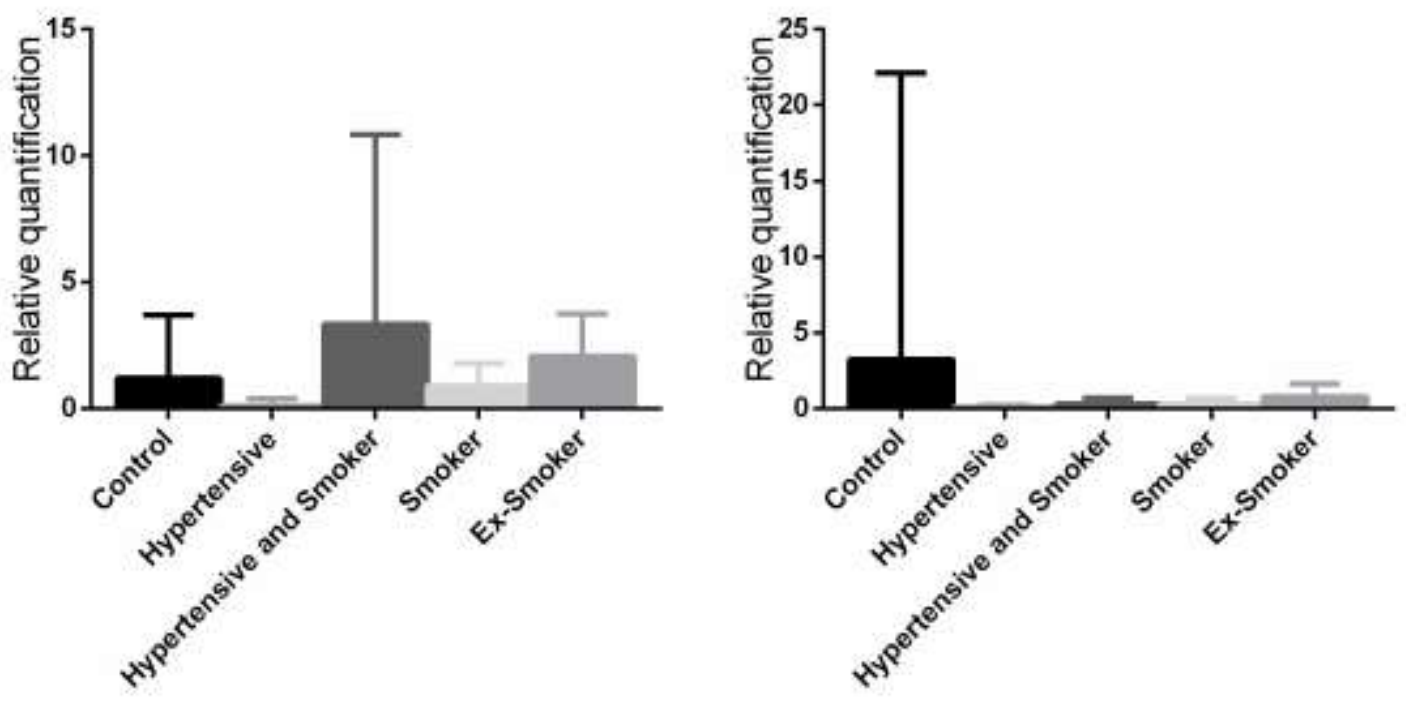

Source: Authors. 
Figure 3 - Comparisons among the groups of the data for apolipoprotein, interleukin 6, osterix, prostaglandin E2 synthase, bone sialoprotein, and transforming growth factor- $\beta$ genes. In the Ex-smoker group, it was observed the higher expression of APO, IL6, OSX, PGE2, and BSP.
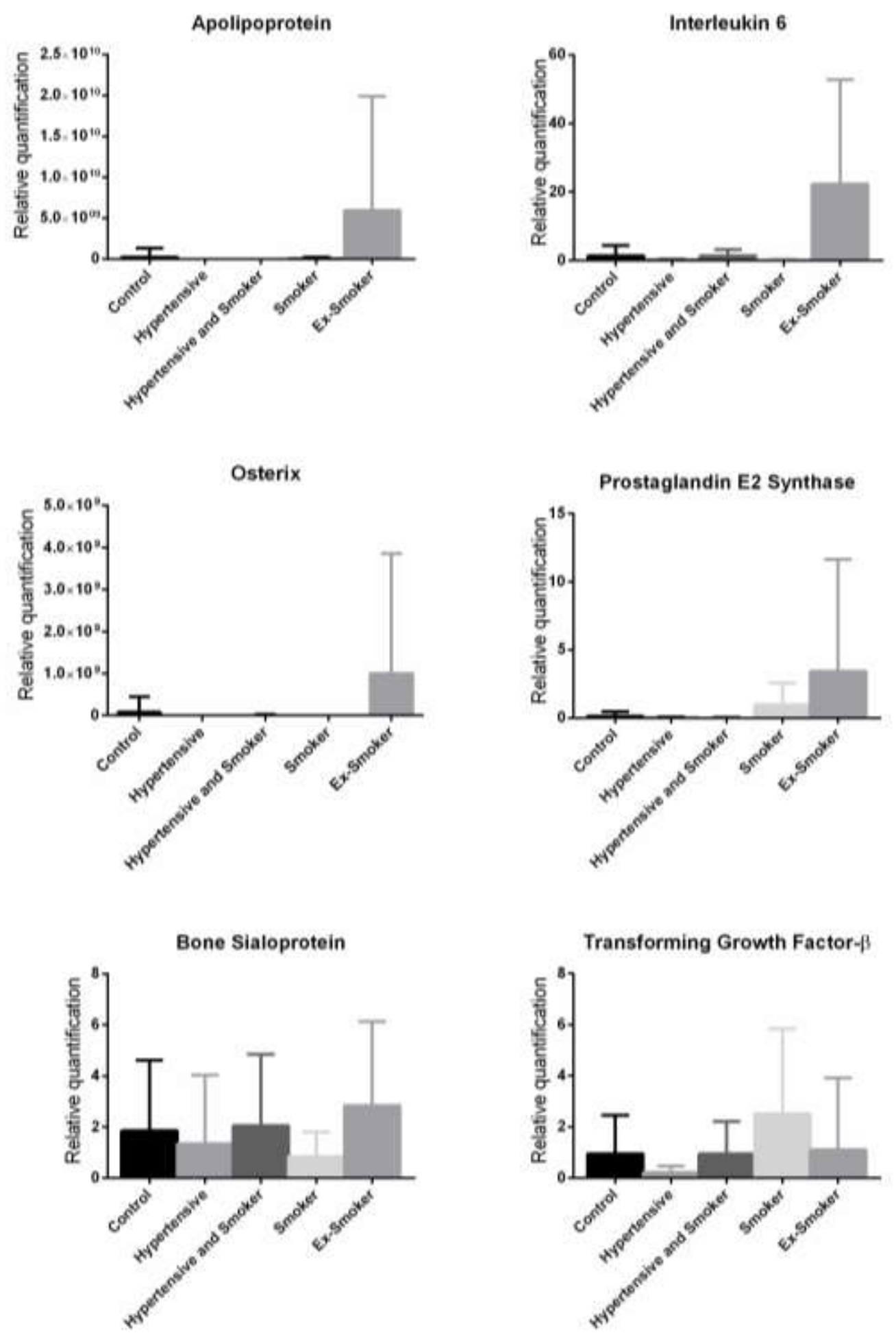

Source: Authors. 
M-CSF, Osteonectin, Bone Morphogenetic Protein II and Integrin presented expression with similar patterns among the groups. The Ex-smoker group presented the highest values and the Hypertensive group the lowest values. All smokers demonstrated expression values comparable to the Control group (Figure 1).

Osteopontin, RUNX 2, and ALP presented similar expression patterns among the groups. The highest expression was observed in the Hypertensive and the Smoker group, and the lowest in the Hypertensive group. Smokers, Ex-smokers, and the Control group demonstrated similar values (Figure 2). Osteocalcin expression was much higher in the Control group when compared to all the other groups (Figure 2).

The Ex-Smoker group presented the highest values in Apolipoprotein, Interleukin 6, Osterix, and Prostaglandin E2 Synthase, with all the other groups demonstrating much lower values when compared to the Ex-Smoker group. Prostaglandin E2 Synthase expression was higher in the Smoker group when compared to the control group (Figure 3).

The lowest bone sialoprotein expression was demonstrated in the Smoker group. This marker presented a similar pattern in the other groups. The Smoker group presented higher TGF- $\beta$ expression and the Hypertensive group demonstrated lower TGF- $\beta$ expression.

\section{Discussion}

A cell demands several molecules which are usually descendant from the protein synthesis process to properly exert its function. Protein synthesis is ruled by nuclear control from the genes (genomic DNA), which are transcribed into mRNA; protein translation occurs in the cytoplasm (Dermit, Dodel, \& Mardakheh, 2017). The present study compared different health conditions as modifiers of the mRNA expression of inflammatory proteins and bone metabolism markers in the alveolar bone. We proposed to better understand why smokers lose more implants than non-smokers. Therefore, we choose real-time PCR as a tool to quantify gene expression and then we compared the groups.

The high prevalence of patients under therapy for high blood pressure in this study motivated the inclusion of this group in the comparisons even though there is no evidence that hypertensive patients are at risk of future implant failure. According to Seki et al., a significant difference was observed in the probing pocket depth $3.8 \pm 1.3 \mathrm{~mm}$ in the antihypertensive group when compared to $3.0 \pm 0.7 \mathrm{~mm}$ in the healthy control group. The treated group demonstrated a larger percentage of peri-implantitis (26.5\%) when compared to $4.7 \%$ of the healthy patients(Seki, Hasuike, Iwano, \& Hagiwara, 2020). According to Mulinari-Santos et al., hypertension is not only associated with cardiovascular diseases, but also with alterations in bone quality. Concerning this group, the data in our study was remarkably interesting, as the transcripts were all downregulated when compared to all the other groups. The most frequent antihypertensive in this group was losartan, an angiotensin receptor antagonist.

In a genetic screening, the angiotensin II type I receptor (AT1R) was listed as a potential determinant of osteogenic differentiation and bone formation. The silencing of AT1R expression by RNA interference severely impaired the maturation of a multipotent mesenchymal cell line (W20-17) along the osteoblastic lineage (Querques et al., 2015). All the studied downregulated transcripts are necessary in the maturation described above. The bone marrow aspirates used herein to perform gene expression analysis included a complex mixture of mesenchymal and hematopoietic cells at different ratios. The effect of losartan was demonstrated in downregulating these genes in the mixture of cells.

Aydoğan et al. reported that treatment with losartan significantly increased 25-hydroxy vitamin D levels, decreased parathormone (PTH), bone-specific alkaline phosphatase, osteocalcin and interleukin 6 (Aydoğan, Erarslan, Ünlütürk, \& Güllü, 2019), as observed herein.

Additional cell culture assays in which cells were treated with losartan displayed an appreciable decrease of activated (phosphorylated)-Smad2/3 proteins. The authors believe that the mechanism of Angiotensin II action in bone metabolism 
appears to be mediated by TGF $\beta$ and targets the proliferation of osteoblast progenitor (Querques et al., 2015). Accordingly, TGF $\beta$ lowest expression was demonstrated in the Hypertension group in the present study.

The first goal of this study was to detect a genetic component from observational data; however, we admit the limitation of small sample size, mainly in the Smoker group. The patients in our institution assume the material costs of implant rehabilitation. The cost of implant treatments compared to conventional treatments remains an obstacle for the option of implant-supported oral rehabilitation. This reduced number may be explained through the observation of Gagné et al.; smoking participants were more likely to be from a more modest socio-professional background than the national average (France) (Gagné, Omorou, Kivits, Alla, \& Minary, 2018). Smokers in São Paulo, Brazil, are predominantly male, young, and single, with socioeconomic drawbacks (illiterate or only having a few years of formal education, people with no employment relationship and receiving social benefits from the government), and having low financial capacity (Oliveira, Santos, \& Furegato, 2019).

Important advances about implant loss and genetic pathways have been described by a Brazilian research group (Broker et al., 2018; Montes et al., 2009, 2007; Pigossi et al., 2012). The main objective of the studies was to answer why some patients present dental implant failure without a clear clinical motive. Allele C of polymorphism rs2009658 of the Lymphotoxin alpha gene was associated with dental implant loss, as well as the presence of teeth and a greater number of placed implants (Broker et al., 2018); vitamin D receptor gene may be a genetic risk marker for dental implant loss in patients who have lost two or more dental implants(Pereira et al., 2019); there was a significant difference in the presence of the alleles presenting polymorphisms in the MMP-8 gene and MMP-1 (Santos, Campos, Souza, Trevilatto, \& Line, n.d.) between the control group and early implant loss group (Costa-Junior et al., 2013). Furthermore, the $+33 \mathrm{C}$ allele for the interleukin 4 gene was associated with susceptibility to dental implant loss (Pigossi, Alvim-Pereira, Alvim-Pereira, Trevilatto, \& ScarelCaminaga, 2014). An explanation for all these polymorphisms influencing implant loss is that intronic polymorphism interferes in exon splicing, which may, in turn, alter the primary protein structure and consequently its function (Broker et al., 2018).

IL-1 (Maria I.G. Campos et al., 2005), IL-2, IL-6 (Maria Isabela Guimarães Campos et al., 2005), IL10 (Pigossi et al., 2012) and MMP-9 (Santos et al., n.d.) polymorphisms were not associated with susceptibility to dental implant failure in the studied population. Genetic predisposition may influence the osseointegration process failure through the accumulated effect of multiple polymorphisms (Dirschnabel et al., 2011).

Although we recognize the importance of gene mutations and polymorphisms as predictors of implant loss risk, we consider it is important to find out whether normal genes with altered expressions may explain the mechanisms involved in implant loss.

Prostaglandin E2 synthase, which produces an important cytokine to bone metabolism and inflammation was upregulated in the Smoker group and the Ex-Smoker group. High prostaglandin E2 levels may lead to increased bone loss, resulting in a less favorable outcome or implant failure (Maria I.G. Campos et al., 2005). Conversely, IL-6 was downregulated in the Smoker group and upregulated in the Ex-Smokers. Major anti-inflammatory cytokines include IL-1 antagonist receptor, IL-4, IL-6, IL-10, IL-11, and IL-13 (Opal \& DePalo, 2000). We consider the hypothesis that smoking delays anti-inflammatory pathways though IL-6 in a reversible way, in the case of stopping smoking.

The comparison between the Smoker group and the Ex-Smoker group presented interesting results for TGF- $\beta 1$, with the latter demonstrating it to be downregulated. Since the Control group expressed less TGF- $\beta 1$, it seems like a restorative expression pattern after stopping the addiction. Bone formation involves several steps from the recruitment of osteoblast precursor cells to calcification of the extracellular matrix, and a variety of cytokines, growth factors, and other macromolecules take part in these events (Maria Isabela Guimarães Campos et al., 2005). TGF- $\beta 1$ is a pleiotropic and ubiquitous cytokine involved in bone development and bone remodeling (Saiganesh et al., 2019). Osteocytes directly remodel their 
perilacunar/canalicular matrix controlling bone quality through TGF- $\beta$ signaling (Dole et al., 2017), and TGF $\beta$ regulates the proliferation of osteoblast progenitor (Querques et al., 2015) cells, as seen above.

Osteocalcin, RUNX2 and bone sialoprotein were downregulated in the Smoker group compared to the Control group and upregulated when the patient stopped smoking. The expression of these various proteins characterize the bone phenotype and are induced during osteoblastic differentiation in a stepwise fashion, suggestive of multiple regulatory factors (Rodan \& Noda, 1991). Kim et al. concluded that the downregulation of RUNX2, BMP-II, peroxisome proliferator-activated receptor gamma-2 (PPARg-2), and upregulation of RANKL/OPG ratio was correlated with early peri-implant marginal bone loss (Kim, Kim, Cha, Lee, \& Kim, 2019). To reach this conclusion, the authors isolated and cultured human alveolar mesenchymal stromal cells derived from bone chips obtained by low-speed drilling during implant placement.

$\beta 1$ Integrin transcript was higher in the Smoker and Ex-Smoker groups compared to the Control group. This seems like a resorptive propensity since integrins are extremely important in osteoclast function. Osteoclasts attach to the bone matrix by means of integrins during bone resorption. Blocking $\beta 1$ Integrin resulted in inhibiting resorption (Helfrich et al., 1996).

The upregulation of M-CSF in the Smoker and Ex-smoker groups appears to present resorption evidence when compared to the control group. Osteoclast formation involves interaction between stromal cells and preosteoclasts which are derived from monocyte lineages. M-CSF only stimulates bone resorption when it is dependent on the generation of new osteoclasts. Its mechanism of action might be directly on osteoclast precursors or indirectly on accessory cells influencing osteoclast generation (Corboz et al., 1992).

The Hypertension and Smoker group presented intriguing results. The quantifications in most genes remained comparable to the Control group, while it demonstrated the highest values of RUNX2, Osteopontin, and alkaline phosphatase expression. Conversely, there were no significant differences in a cross-sectional study investigating the associations between ALP level and hypertension in current smokers, which means that ALP liver production was not affected by the patient's smoking (Shimizu et al., 2013). The osteopontin concentration was significantly higher in the hypertensive subjects in comparison with the normotensive subjects but did not differ when treated and untreated hypertensive subjects were compared in the study by Stępień et al. (2012).

\section{Conclusion}

This preliminary work demonstrated some discrepancies in the gene expression panel. In summary, gene downregulation was observed in patients under anti-hypertensive therapy. Smoke seems to reduce expression of genes involve in bone formation and increase genes responsible for resorptive activity. This pattern of genic expression may be involved in higher implant loss, observed in smokers. Stop smoke seems to return expression of some of these genes.

\section{Acknowledgements}

This work was partly supported by the Coordination for the Improvement of Higher Education (CAPES Coordenação de Aperfeiçoamento de Pessoal de Nível Superior - Brasil) - Finance Code 001, in São José dos Campos, Brazil

\section{References}

Aydoğan, B., Erarslan, E., Ünlütürk, U., \& Güllü, S. (2019). Effects of telmisartan and losartan treatments on bone turnover markers in patients with newly diagnosed stage I hypertension. JRAAS - Journal of the Renin-Angiotensin-Aldosterone System, 20(3). https://doi.org/10.1177/1470320319862741

Becker, S. T., Beck-Broichsitter, B. E., Rossmann, C. M., Behrens, E., Jochens, A., \& Wiltfang, J. (2016). Long-term Survival of Straumann Dental Implants with TPS Surfaces: A Retrospective Study with a Follow-up of 12 to 23 Years. Clinical Implant Dentistry and Related Research, 18(3), 480-488. https://doi.org/10.1111/cid.12334 
Broker, R. de C., Doetzer, A. D., de Souza, C. M., Alvim-Pereira, F., Alvim-Pereira, C. C., \& Trevilatto, P. C. (2018). Clinical aspects and polymorphisms in the LTA, TNFA, LTB genes and association with dental implant loss. Clinical Implant Dentistry and Related Research, 20(6), 954-961. https://doi.org/10.1111/cid.12677

Campos, Maria I.G., Santos, M. C. L. G., Trevilatto, P. C., Scarel-Caminaga, R. M., Bezerra, F. J. B., \& Line, S. R. P. (2005). Evaluation of the relationship between interleukin-I gene cluster polymorphisms and early implant failure in non-smoking patients. Clinical Oral Implants Research, 16(2), 194-201. https://doi.org/10.1111/j.1600-0501.2004.01091.x

Campos, Maria Isabela Guimarães, Godoy Dos Santos, M. C. L., Trevilatto, P. C., Scarel-Caminaga, R. M., Bezerra, F. J., \& Line, S. R. P. (2005). Interleukin2 and interleukin-6 gene promoter polymorphisms, and early failure of dental implants. Implant Dentistry, 14(4), 391-398. https://doi.org/10.1097/01.id.0000188470.54417.98

Chambrone, L., Preshaw, P. M., Ferreira, J. D., Rodrigues, J. A., Cassoni, A., \& Shibli, J. A. (2014). Effects of tobacco smoking on the survival rate of dental implants placed in areas of maxillary sinus floor augmentation: A systematic review. Clinical Oral Implants Research, 25(4), 408-416. https://doi.org/10.1111/clr.12186

Corboz, V. A., Cecchini, M. G., Felix, R., Fleisch, H., van der Pluijm, G., \& Löwik, C. W. (1992). Effect of macrophage colony-stimulating factor on in vitro osteoclast generation and bone resorption. Endocrinology, 130(1), 437-442. https://doi.org/10.1210/endo.130.1.1727717

Costa-Junior, F. R., Alvim-Pereira, C. C., Alvim-Pereira, F., Trevilatto, P. C., de Souza, A. P., \& Santos, M. C. L. G. (2013). Influence of MMP-8 promoter polymorphism in early osseointegrated implant failure. Clinical Oral Investigations, 17(1), 311-316. https://doi.org/10.1007/s00784-012-0699-z

Dermit, M., Dodel, M., \& Mardakheh, F. K. (2017). Methods for monitoring and measurement of protein translation in time and space. Molecular BioSystems, 13, 2477-2488. https://doi.org/10.1039/c7mb00476a

Dirschnabel, A. J., Alvim-Pereira, F., Alvim-Pereira, C. C., Bernardino, J. F., Rosa, E. A. R., \& Trevilatto, P. C. (2011). Analysis of the association of IL1B(C-511T) polymorphism with dental implant loss and the clusterization phenomenon. Clinical Oral Implants Research, 22(11), 1235-1241. https://doi.org/10.1111/j.1600-0501.2010.02080.x

do Prado, R. F., Rabêlo, S. B., de Andrade, D. P., Nascimento, R. D., Henriques, V. A. R., Carvalho, Y. R., \& de Vasconcellos, L. M. R. (2015). Porous titanium and $\mathrm{Ti}-35 \mathrm{Nb}$ alloy: effects on gene expression of osteoblastic cells derived from human alveolar bone. Journal of Materials Science: Materials in Medicine, 26(11). https://doi.org/10.1007/s10856-015-5594-0

Dole, N. S., Mazur, C. M., Acevedo, C., Lopez, J. P., Monteiro, D. A., Fowler, T. W., \& Alliston, T. (2017). Osteocyte-Intrinsic TGF- $\beta$ Signaling Regulates Bone Quality through Perilacunar/Canalicular Remodeling. Cell Reports, 21(9), 2585-2596. https://doi.org/10.1016/j.celrep.2017.10.115

Gagliardi, C. F., de VasConCellos, L. M. R., Cairo, C. A. A., Rabelo, S. B., \& Do Prado, R. F. (2018). Expression of BMP ii by human osteoblasts cultivated on dense or porous titanium. Brazilian Dental Science, 21(3), 275-281. https://doi.org/10.14295/bds.2018.v21i3.1586

Gagné, T., Omorou, A. Y., Kivits, J., Alla, F., \& Minary, L. (2018). Socioeconomic profile and smoking among adolescents in vocational training. Revue d'Epidemiologie et de Sante Publique, 66(6), 375-383. https://doi.org/10.1016/j.respe.2018.09.005

Helfrich, M. H., Nesbitt, S. A., Lakkakorpi, P. T., Barnes, M. J., Bodary, S. C., Shankar, G., \& Horton, M. A. (1996). $\beta 1$ integrins and osteoclast function: Involvement in collagen recognition and bone resorption. Bone, 19(4), 317-328. https://doi.org/10.1016/S8756-3282(96)00223-2

Kim, D.-J., Kim, S.-K., Cha, J.-K., Lee, J.-S., \& Kim, C.-S. (2019). Clinical Factors and Cellular Responses of In Situ Human Alveolar Bone-Derived Mesenchymal Stromal Cells Associated With Early Periimplant Marginal Bone Loss: A Prospective Cohort Pilot Study. Implant Dentistry, 28(5), 421-429. https://doi.org/10.1097/ID.0000000000000904

Livak, K. J., \& Schmittgen, T. D. (2001). Analysis of Relative Gene Expression Data Using Real-Time Quantitative PCR and the 2- $\Delta \Delta C T$ Method. Methods, 25(4), 402-408. https://doi.org/10.1006/meth.2001.1262

Maheaswari, R., Kshirsagar, J. T., \& Lavanya, N. (2016). Polymerase chain reaction: A molecular diagnostic tool in periodontology. Journal of Indian Society of Periodontology, Vol. 20, pp. 128-135. https://doi.org/10.4103/0972-124X.176391

Montes, C. C., Alvim-Pereira, F., de Castilhos, B. B., Sakurai, M. L. L., Olandoski, M., \& Trevilatto, P. C. (2009). Analysis of the association of IL1B $(\mathrm{C}+3954 \mathrm{~T})$ and IL1RN (intron 2) polymorphisms with dental implant loss in a Brazilian population. Clinical Oral Implants Research, 20(2), 208-217. https://doi.org/10.1111/j.1600-0501.2008.01629.x

Montes, C. C., Pereira, F. A., Thomé, G., Alves, E. D. M., Acedo, R. V., de Souza, J. R., \& Trevilatto, P. C. (2007). Failing factors associated with osseointegrated dental implant loss. Implant Dentistry, 16(4), 404-412. https://doi.org/10.1097/ID.0b013e31815c8d31

Mulinari-Santos, G., de Souza Batista, F. R., Kirchweger, F., Tangl, S., Gruber, R., \& Okamoto, R. (2018). Losartan reverses impaired osseointegration in spontaneously hypertensive rats. Clinical Oral Implants Research, 29(11), 1126-1134. https://doi.org/10.1111/clr.13376

Oliveira, R. M. de, Santos, J. L. F., \& Furegato, A. R. F. (2019). Prevalence and smokers' profile: Comparisons between the psychiatric population and the general population. Revista Latino-Americana de Enfermagem, 27. https://doi.org/10.1590/1518-8345.2976.3149

Opal, S. M., \& DePalo, V. A. (2000). Anti-inflammatory cytokines. Chest, 117(4), 1162-1172. https://doi.org/10.1378/chest.117.4.1162

Pereira, T. M., Alvim-Pereira, F., Alvim-Pereira, C. C., Ignácio, S. A., de Souza, C. M., \& Trevilatto, P. C. (2019). A complete physical mapping of the VDR gene for dental implant loss: a pilot study. Clinical Oral Implants Research. https://doi.org/10.1111/clr.13529

Pigossi, S. C., Alvim-Pereira, F., Alvim-Pereira, C. C. K., Trevilatto, P. C., \& Scarel-Caminaga, R. M. (2014). Association of Interleukin 4 gene polymorphisms with dental implant loss. Implant Dentistry, 23(6), 723-731. https://doi.org/10.1097/ID.0000000000000157 
Research, Society and Development, v. 10, n. 3, e46910313650, 2021

(CC BY 4.0) | ISSN 2525-3409 | DOI: http://dx.doi.org/10.33448/rsd-v10i3.13650

Pigossi, S. C., Alvim-Pereira, F., Montes, C. C., Finoti, L. S., Secolin, R., Trevilatto, P. C., \& Scarel-Caminaga, R. M. (2012). Genetic association study between Interleukin 10 gene and dental implant loss. Archives of Oral Biology, 57(9), 1256-1263. https://doi.org/10.1016/j.archoralbio.2012.02.020

Querques, F., Cantilena, B., Cozzolino, C., Esposito, M. T., Passaro, F., Parisi, S., \& Pastore, L. (2015). Angiotensin receptor I stimulates osteoprogenitor proliferation through TGFß-mediated signaling. Journal of Cellular Physiology, 230(7), 1466-1474. https://doi.org/10.1002/jcp.24887

Rodan, G. A., \& Noda, M. (1991). Gene expression in osteoblastic cells. Critical Reviews in Eukaryotic Gene Expression, 1(2), 85-98. Retrieved from http://www.ncbi.nlm.nih.gov/pubmed/1802105

Saiganesh, S., Saathvika, R., Arumugam, B., Vishal, M., Udhaya, V., Ilangovan, R., \& Selvamurugan, N. (2019). TGF- $\beta 1$-stimulation of matrix metalloproteinase-13 expression by down-regulation of miR-203a-5p in rat osteoblasts. International Journal of Biological Macromolecules, 132, 541-549. https://doi.org/10.1016/j.ijbiomac.2019.04.003

Santos, M. C. L., Campos, M. I. G., Souza, A. P., Trevilatto, P. C., \& Line, S. R. P. (n.d.). Analysis of MMP-1 and MMP-9 promoter polymorphisms in early osseointegrated implant failure. The International Journal of Oral \& Maxillofacial Implants, 19(1), 38-43. Retrieved from http://www.ncbi.nlm.nih.gov/pubmed/14982353

Seki, K., Hasuike, A., Iwano, Y., \& Hagiwara, Y. (2020). Influence of antihypertensive medications on the clinical parameters of anodized dental implants: a retrospective cohort study. International Journal of Implant Dentistry, 6(1). https://doi.org/10.1186/s40729-020-00231-9

Shimizu, Y., Nakazato, M., Sekita, T., Kadota, K., Yamasaki, H., Takamura, N., \& Maeda, T. (2013). Association between alkaline phosphatase and hypertension in a rural Japanese population: The Nagasaki Islands study. Journal of Physiological Anthropology, 32(1), 10. https://doi.org/10.1186/18806805-32-10

Stpień, E., Fedak, D., Klimeczek, P., Wilkosz, T., Banyś, R. P., Starzyk, K., \& Pasowicz, M. (2012). Osteoprotegerin, but not osteopontin, as a potential predictor of vascular calcification in normotensive subjects. Hypertension Research, 35(5), 531-538. https://doi.org/10.1038/hr.2011.231 